\title{
Transatlantica
}

Revue d'études américaines. American Studies Journal

2| 2017

(Hi)stories of American Women: Writings and Rewritings / Call and Answer: Dialoguing the American West in France

\section{"Memory and Desire": T.S. Eliot, Reaction, Nostalgia, and Poetic Reserve in The Waste Land}

Philippe Birgy

\section{OpenEdition \\ Journals}

Electronic version

URL: https://journals.openedition.org/transatlantica/10944

DOI: 10.4000/transatlantica.10944

ISSN: 1765-2766

Publisher

Association française d'Etudes Américaines (AFEA)

\section{Electronic reference}

Philippe Birgy, "'Memory and Desire": T.S. Eliot, Reaction, Nostalgia, and Poetic Reserve in The Waste

Land", Transatlantica [Online], 2 | 2017, Online since 14 May 2019, connection on 31 January 2023.

URL: http://journals.openedition.org/transatlantica/10944 ; DOI: https://doi.org/10.4000/

transatlantica. 10944

This text was automatically generated on 31 January 2023.

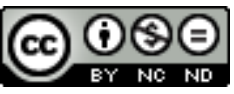

Creative Commons - Attribution-NonCommercial-NoDerivatives 4.0 International - CC BY-NC-ND 4.0 https://creativecommons.org/licenses/by-nc-nd/4.0/ 


\title{
"Memory and Desire": T.S. Eliot, Reaction, Nostalgia, and Poetic Reserve in The Waste Land
}

\author{
Philippe Birgy
}

1 This essay engages with the question of reaction in Eliot's poetry. This question has been a long standing preoccupation among Eliotian scholars and a divisive issue, prompting numerous contradictory assessments of the author's work. For this reason, before I press my inquiry any further, I will recapitulate some of the polemical critical responses it has elicited. Even prior to these, the word "reaction" in itself appears to invite a variety of connotations, which has probably contributed to polarizing the debate along the lines it has subsequently followed. Most prominently, two adjective forms may be derived from it: reactive and reactionary. Bearing this indeterminacy in mind, there are at least three constructions of the term that shall command our attention. The first is political, and it suggests a countermove in the direction of conservatism caused by what the reactionary mind perceives as an assault on distinctions that previously obtained. It also implies that the forces that are advanced in the name of progress and modernity hide a disingenuous purpose and will inevitably prove detrimental to the social order. This acceptation of the word has been used to characterize Eliot's political stance at certain periods of his career. The subject has been variously explored by Charles Ferral (2001) and Paul Morrison (1996) among others. The second acceptation is psychological and betrays some temperamental incapacity to have done with past experiences, to get over them and avoid the entrapments of memory. As often as not, these two motives have been conflated in Eliotian criticism into a single "pathology," as it were.

2 As for the third construction of the term, it is closely correlated to them and involves a perception of time which displaces and complicates the linear movement of history. It involves a sense of belatedness, of coming after the events or the facts, and of being driven by a yearning to reactivate a former pattern of action, in such a way that it disturbs and calls into question any linear or chronological succession of causes and 
effects. Now, if the latter definition seems more directly conducive to textual analysis, still, it leaves us in doubt about its possible relevance in a systematic study of poetic utterance and writing. How can it help define a method of textual analysis and delineate a specific set of tropes, figures and structural traits, without taking into account that the textual construction is entirely independent from the psychological and the political and that it is determined by the three aforementioned acceptations of the term "reaction"? I will address this issue with reference to the poetic and critical status of memory in Eliot's compositional technique.

Reaction can be understood as that play of forces whose consequences Nietzsche traced throughout history and which was systematized after him by Freud thanks to such notions as repression and the unconscious. This Nietzschean influence does not appear to have been fully considered in the appraisal of Eliot's inspiration-an understandable omission since Eliot himself rather flatly dismissed Nietzsche's thought as inconsistent (Eliot, 2014 401-403). Yet he could not have ignored the determining role Nietzsche still played in the intellectual climate of the late nineteenth and early twentieth century, and because this context frames his poetry, I believe that a lot can be gained from distinguishing between the digest of pseudo-Nietszcheanism that has fueled the elitistic claims of modernism channeled by the little magazines ${ }^{1}$ and the aspects of the philosopher's discourse that precisely upturn such preconceptions about tradition and creative enterprise, personality and selflessness, the revolutionary and the reactionary, activity and passivity, the progressive and the retrograde.

\section{Poetry as Neutral Ground: the Limits of Inquiry}

4 As mentioned above, many ambiguities surround the critical legitimacy of the term "reaction," and before expanding on the notion of reaction itself I shall begin with an assessment of various approaches that have suggested its relevance to Eliot's poetry. This preliminary examination is intended to give a general methodological framework to what follows.

5 The opening lines of The Waste Land and more particularly the poetic phrase "mixing memory and desire" have persistently captured the interest and imagination of scholars and inspired numerous commentaries, from Grover Smith's T.S. Eliot and the Use of Memory to Fred Crawford's Mixing Memory and Desire, and more recently Gabrielle McIntire's Modernism, Memory, and Desire. The formula will be of interest to us insofar as the predication of desire on reminiscences of a lost object, rather than on futureoriented projections, corresponds to one of the possible constructions of the term reaction.

6 "[M]ixing memory and desire" has frequently been taken not merely as a case of poetic license, but as a logical puzzle, a paradoxical pronouncement that called for theoretical clarifications. It could easily be argued that such requirements went against Eliot's observation that the point of poetry was poetry itself, not the ideas supposedly hidden behind it, the latter-however unclear-remaining mostly instrumental. ${ }^{2}$ Yet he uttered and even couched on paper as many statements suggesting exactly the reverse. ${ }^{3}$

7 Moreover, it is not certain that Eliot's 1923 poetic production can be measured by standards that he only set for himself in 1928, after he had reached a major turning point in his intellectual life. Which is even truer if some of the material of The Waste 
Land were drafted between 1911 and 1914, as Grant alleges (1982, 4). Applying Eliot's criticism to his own work was surely a temptation that the early commentators frequently-and understandably-yielded to. ${ }^{4}$ But any periodization of Eliot's work is equally debatable for one could well argue with Shusterman that Eliot had been to great lengths to preserve the overall coherence of his production, and align his subsequent theoretical pronouncements with his preceding production.

Much in the same way, Eliot's own personal assessment as a "classicist in literature, royalist in politics, and Anglo-Catholic in religion"5-an explicitly reactionary claim insofar as it strongly contests the benefits of modernity-can be understood as an invitation to keep the different fields of his public production, if not tightly, at least reasonably compartmented, and many extended scholarly assessments of Eliot seem to conform to his own recommendation by distinguishing the social commentator and the secular moralist from the religious man, and the poet from the philosophy student. ${ }^{6}$ Yet, undoubtedly, that same authorial statement quoted above could as easily be used to illustrate the opposite principle. If not, why mentioning these aspects in preamble to a collection of critical essays specifically dealing with literature?

Be it as it may, most of the accusations leveled at the poet qua poet by reason of his reactionary leanings rest, understandably, on that biographical ground. And to this day, the amount of personal strategy involved in the hypothetical compartmentalizing of Eliot's activity remains a debated issue. As Smith rightly notes, in Tradition and the Individual Talent, Eliot clearly establishes the moral responsibilities of authors (Smith 22). By any standard, the relationship between the private person, the public persona of Eliot, and his poetic utterances is a vexed question that I am not at leisure to expose accurately in these pages. It certainly reaches back well into the nineteenth century. The Parnassiens' divorce with realism, performatively enacted in their writing, already begged the question of the moral responsibility of art and was inseparable from the debate around poetry and its ideas.

Accordingly, I shall content myself with the mention of one aspect of that critical discord among Eliot specialists, although the reader must remain aware that in so doing, I merely isolate a strand in a complex mesh of critical relationships whose implications are notably more intricate and contradictory. The trend that will command my attention is that in the eyes of a generation of critics who, from the $1980 \mathrm{~s}$ onward, programmatically expressed a deep concern for the ideological subtext of Eliot's writings, his avoidance of clear ideological commitment manifested an "escapist" tendency of modernism that was increasingly stigmatized in scholarly works of that period.' Such evasions, it was argued, might have been a strategy of the modernists to deflect personal responsibilities regarding the interpretations of the political tenor of their literary writings. For those were remarkably past-oriented, yearning retrospectively towards an ancient order, elitist and anti-democratic. These beliefs, however, could not be presented in so many words, or they would have been at variance with the modernist ambition to renew literature.

11 This critical move implied a reexamination of modernism, since it seemed that some of its early exponents had purported to place it beyond common judgment. ${ }^{8}$ Terry Eagleton thus defended the idea that New Criticism was largely to blame for sealing off the domain of aesthetic from other mundane preoccupations. In his wake, scholars later redirected their attention to the combined question of Eliot's political temperament, his reactionary statements, his position on tradition and classicism, that 
is: relating the aesthetic and the political. of course, one may object that, somehow, this critical position was merely a return to moral and biographical criticism under a veneer of new historicism. Suffice it to say that it was not a new trend, for the issue had already become a bone of contention at the moment of Eliot's conversion and his publication of the Essays For Lancelot Andrews, when many readers had regretted the discontinuity between the postures he had adopted in his social and moral criticism, on the one hand, and in his poetry on the other hand.

Concurrently, Eliot's private affects (whether opposed to or constitutive of his poetic personae) were investigated by Maud Ellman (1988) and Eloise Knapps Hay (1982), to cite but a few. The subject was revisited by recent feminist theory (Lamos 2009) and the movement was prolonged by McIntire's publication where she endeavors to bring together the strands of sexuality and writing in her account of Eliot's work-once more against Eliot's doctrine of impersonality.

In short, all critical commentators mentioned above have fastened upon the apolitical and impersonal posture of Eliot as an indicator of his anticipation of future criticism and his keen awareness of a sense of impropriety, as if a streak of bad conscience had resulted in the deliberate or semi-conscious obfuscation of whatever in his poetic expression exposed it to species of criticism informed by his political standards. This supposition leads to another: admitting that much, one would also have to accept that such censure was primarily exercised by Eliot against his own conceptions and anticipations, hence reflecting a mental schism or interiorized state of adversity.

Such is the background-or at least the most relevant part of the background-to the subject of Eliot's political standing and characterial predispositions, as manifested in his poetic writings. These have obviously a lot to do with memory processes and formations, as well as with the reactive operations of the mind. While taking them into consideration and remaining largely concerned with the problem of reaction, I propose to follow another slightly different line of inquiry by narrowing the focus down to the internal textual functioning of the first section of The Waste Land. Isolating in it what seems to corroborate a certain positioning of the narrative personae vis-à-vis the past, I shall observe the textual operations whereby the poetic voices re-connect with it, how the past is retrieved and re-appropriated via the play of affects, and how the vital forces of Eros are determined in relation to it and mobilized as poetic energy (desire being one of the main thematics introduced in the opening sequence of the poem).

of course, such a program may suggest that sticking to purely stylistic observations does not commit us to any particular critical hypothesis. Actually, it is far from being the case: although I will provisionally maintain that posture to further my argument, in truth, I already presume here that reactivity, acting under the sway of resentment, being drawn to the past, experiencing nostalgia and reactionary leanings are all correlated in some way.

\section{Intra- and Inter-Textual Reactions}

16 The incipit to The Waste Land is frequently quoted as a canonical example of enjambment. The run-on lines are certainly conducive to an effect of accumulation, overburdening the stanza and by implication overwhelming the poetic persona.

APRIL is the cruelest month, breeding

Lilacs out of the dead land, mixing 
Memory and desire, stirring

Dull roots with spring rain.

Winter kept us warm, covering

Earth in forgetful snow, feeding

A little life with dried tubers.

Summer surprised us, coming over the Starnbergersee

With a shower of rain; (Eliot, 2006 57, 1.1-9)

French prosody further distinguishes between rejet and contre-rejet, and it is obviously the second term that applies to the opening lines of the poem. It is not that each verse encroaches upon the next or that the intention is delayed, but rather that the main bulk of each successive phrase (and not clause) is weakened by the subtraction of the verbal element, so that it is devitalized, and remains inconclusive. This process could be described as a species of "retention" which does not allow for any proper beginning or ending.

One may be tempted to dismiss these inferences as a case of over-interpreting-or perhaps simply of interpreting-the lines to forward our argument. Yet this retentive process ("retentive" is an interesting word in the present context since it also means "good at remembering") has many tangible consequences: by holding back the first term of each predication, it throws into relief the words "breeding," "mixing," and "stirring," causing a displacement or misalignment in the prosody and, most conspicuously, imposing a series of gerunds in the place of the rhyme: in terms of versification, it is admittedly a weak rhyme which dulls the stanza and only imparts it with "little life" (the same technique is pursued in the next lines with the gerunds "covering" and "feeding").

Coming back to "breeding," the first word in the series, it may have implications of renewed life or liveliness that tie up very explicitly with the sacrificial vegetation myths of regeneration documented by the author in the notes and with their sexual connotations. But here, the use is dysphoric, and connotes some kind of vegetative life. As for the possibility of recovery and revitalization of a past, it remains extremely hazy. For this reason, the notion that Eliot's statement-"it is interesting to cut yourself to pieces once in a while and wait to see if the fragments will sprout," as quoted by McIntire (76)-actually pre-figures The Waste Land remains debatable. It is more tempting to see it as a learned reference to Frazer, because that possibility of regeneration is, according to Frazer's anthropology, the core of the rites and myths he compiles in The Golden Bough $(351-60 ; 368-9)$ and Eliot uses the sacrificial myth as a metapoetic device, a structural motif or symbol. I will not recapitulate the terms of the dispute around the exact function of the myth in Eliot's poetry, for it has been abundantly and conclusively debated among scholars. Let me just venture one remark which will prove useful in the course of the following developments. If, according to the doctrine of impersonality, the fragments collated in the poem somehow possess a sort of evocative integrity and retain the faculty to conjure up states of mind and emotional dispositions, one must suspect that they possess their own inner nature and purpose, and that their potential may realize itself in any new context. In the same way, the pieces of oneself, like so many seeds sown into the ground, might germinate and fructify. Admittedly nothing specifies that the fragments in question are those of the past. Insofar as they are meant to provide an index of contemporary modernity, they are not necessarily reminiscent of anything marked off temporally. Some of them 
are, though, and they strongly intimate the possibility that something of the past is still to come, that its unrealized potentialities could still be activated.

The term "myth," with its suggestion of a superior fiat before which the individual should yield, can be confusing. The impersonal classicism of Eliot as modernist, at its most dignified, may consist in retaining something of the past that harbors a life force and a capacity to develop which exceed the simple preservation of the solipsistic self of the Romantic, with its private états d'âme. Further on, I will argue that this position might be defined as reactionary in a sense that calls into account the common critical use of the term. Something has to be kept and remembered: perhaps the common poststructuralist pun on "re-membering" has obscured the sweeping urgency and breadth of this imperative, as the manifestation of a will that is not selfishly personal yet that remains strongly and determinedly centered and authoritative in its expression. It does not surrender to an external force that would speak through it and realize some superior purpose-as abnegation would require.

21 As I have suggested above, the verbs used in "The Burial of the Dead" are ambivalent. "Stirring" may imply "animating," but it also denotes blending and confusion, just as "mixing" may designate both a combination and a muddle. Such ambivalences reveal the extent to which the text works against itself. On the one hand, it struggles with the past-an operation that I will come to associate specifically with reaction. On the other hand feelings are mediated by distancing devices which ward off the danger of being contaminated and confused by overwhelming emotional intensities, whether sublime, sordid or pathetic. The surprise caused by the summer is preceded by a reflexive passage that frames it, voices are estranged by the recourse to German language or the use of inverted comas. Antithetic statements call each other into question (1. 16-7; 36-7), and the promises of revelation are grim and discouraging (1. 26-30). Above all, all the Romantic situations involving lovers (here "Romantic" must be understood in a vulgar sense) are counterpointed by modern equivalents that lack all dignity (the typist, the high-strung lady, the married woman at the bar).

Maud Ellman and Eloise K. Hay choose to treat this distrust of feelings as the symptoms of a masculine fantasy of control prescribing authoritative self-discipline. Here again, the stress laid on the preservation of order and hierarchic status quickly prompts associations with a reactionary agenda. These proceed from the common construction of the reactionary as that person who fears that the integrity of his neurotic self will be endangered by the indulgence of repressed desires that he does not recognize as his "own," that do not belong to his constitution. But as it has already been suggested, one might as readily contend that it is precisely the strictures of the personal constitution, the very limitative sense of one's "own self," that the reactionary modernist finds problematic. To that extent, the reactionary turn of mind squares with modernist thinking, when fully unfolded.

23 And if one feels disinclined to fold back the poem on the poet to subject it to a psychological treatment, the reticence expressed in The Waste Land can equally be interpreted as a fear that the author's personal-extraneous and solipsistic-moods (and more generally, all points of eloquence and passionate intensity) might compromise the balance of the text, implying that the latter virtually possesses some internal coherency whose realization requires that it obeys its own inner imperatives. This is consistent with the unidentified dispassionate, negative and deflationary voice which curbs the emotional outbursts of fretful characters and reminds them of the 
limits of human understanding, as in lines 19-30, or in the retort to the apprehensive inquiries of the overwrought woman in "A Game of Chess":

"My nerves are bad to-night. Yes, bad. Stay with me.

"Speak to me. Why do you never speak? Speak.

"What are you thinking of? What thinking? What?

"I never know what you are thinking. Think."

I think we are in rats' alley

Where the dead men lost their bones. (Eliot, 2006 1. 115-25) conclusive image:

The voice of the thunder which frames the last section of The Waste Land also explicitly phrases a rebuttal and a closing statement:

After the torchlight reel on sweaty faces

After the frosty silence in the gardens

After the agony in stony places (Eliot, 2006 1. 322-4)

A defining trait of the passage that is significantly related to the equivocations I have mentioned is the particular affect foregrounded in the passage-nostalgia, whose etymology combines algia (suffering) and nostos, the way back home. Literally, that combination signifies homesickness, the yearning for one's native soil or land. And the earth is actually where one starts from in "The Burial of the Dead." For our present purpose, nostalgia may roughly be construed as a negative affect insofar as it combines two conditions: the impossibility to go back home and the poignancy of the irretrievable moments that have gone missing. Moreover, the burning sting that its evocation occasions evidently results from the consciousness of an unrealized potential of that past. Somewhere, at a preceding time point, a thriving life was cut short, its development aborted.

In The Waste Land, nostalgia is all invasive but it is simultaneously contained by the quotation marks which, in keeping with the doctrine of impersonality, act as a prophylactic device to prevent any emotional overflow, as though the balance of the poem itself would be at risk. These are conspicuously present in lines 35-36 for instance ("You gave me hyacinths first a year ago; / "They called me the hyacinth girl.") or lines 102-103 ("And still she cried, and still the world pursues, I 'Jug Jug' to dirty ears"). They often appear in conjunction with line breaks that further isolate the disturbing utterances, as can be seen in lines 111-114, or in 282-99 where an embedded quotation further emphasizes the distrust of inordinate declarations:

"My feet are at Moorgate, and my heart

Under my feet. After the event

He wept. He promised 'a new start.'

I made no comment. What should I resent?" (Eliot, 2008 66, 1. 296-299)

One noticeable exception is the exclamatory voice that intervenes at the end of line 69 ("There I saw one I knew, and stopped him, crying, "Stetson!") in the London bridge sequence (76). But in so doing, it explicitly cuts short the progression of the character. Besides, the flowing movement of the crowd which had disconcertingly started with a headless sentence has already been brought to a stop in the previous line by a very

Flowed up the hill and down King William Street,

To where Saint Mary Woolnoth kept the hours

With a dead sound on the final stroke of nine. (Eliot, 2006 59, 1. 66-8)

Moreover, the emotional and moral significance of the following address, which one might associate with its lyrical eloquence, is just as decisively countered by a final verse 
discounting any possibility of sincerity ("You! hypocrite lecteur!--mon semblable,mon frère!") and is paradoxically contained within the same quotation marks.

As a consequence, the incipit of The Waste Land may be precisely understood as a negation of negative affects. Here, a voice laments some natural necessity which imposes remembrance when forgetfulness would be more innocuous or preferable. of course it would be a dubious shortcut to construe that pronouncement as an authorial statement to the effect that reminiscence as a poetic method would be harmful or unsatisfactory. And at any rate, it is not reminiscence in itself-the use of memory-but the erotic investment of it, as McIntire remarks (39-44), that is disturbing when it prods or goads, when it cuts to the quick, and hence quickens, stirs, re-vitalizes and revives (as when "the weak spirit quickens" in "Ash Wednesday").

\section{The Reaction against Romanticism}

If we are to believe his commentators, Eliot's critical objection to the notion of Romantic genius is at work in his poetic writing. Peter Faulkner, in his introduction to A Modernist Reader, argues for instance that Eliot's notion of objective correlative "contradicts the Romantic idea of poetry as the direct expression of emotion" (Faulkner, 1986 21). In his essay on Wordsworth and Coleridge, Eliot writes that he "would not be understood as affirming that revolutionary enthusiasm is the best parent for poetry or as justifying revolution on the ground that it will lead to an outburst of poetry-which would be a wasteful and hardly justifiable way of producing poetry" (Eliot, 1958 75). Following that line of reasoning, he eventually concludes that the sudden creative effulgence of inspiration is not conducive to valuable artistic achievements: "To me it seems that at these moments, which are characterized by a momentary lifting of the veil of anxiety and fear which presses upon our daily life so steadily that we are unaware of it, what happens is something negative" (Eliot, 1958 144). Such pronouncements discredit the idea of a pure creation that would not be firmly secured to memory through the exact reconstitution of a set of objects cohering into a situation and corresponding to an experience. What they call into question is the notion of a visionary projection towards the future. The many evocations of amorous (or sexual) encounters that fail to open up any new vista intimate that much. The conciseness of the typist's "well now that's done: and I'm glad it's over" (252-253) is undermined by the ambivalence of the terms which only fleetingly suggests an achievement but immediately insinuates the sense of having gone through an ordeal so as to leave it behind, drawing something to its conclusion, having gone through the motions, etc.

The political implications of the aversion to Romanticism is another problem that has been extensively covered by Eliot's commentators. In the discourse of Maurras and Hulme, as in that of the more ordinary reactionaries, Romanticism is clearly identified as the main antagonist, the arch enemy against which their programme must be set up in defense. Likewise, Babbitt used it as a foil to promote his doctrine of discipline and order (see Bornstein). But ever since 1957 and the publication of Kermode's Romantic Image, the myths of the anti-Romantic history of modernism have been called into question. Both Kermode and C.K. Stead described Eliot as a continuator of the Romantic tradition. In their wake, Edward Lobb (1981) argued that Eliot's vision of literary history was mainly Romantic insofar as it consisted in a nostalgic longing for a golden 
age necessarily situated in the past. Eventually Lobb concluded that Eliot had found in his reading of the Romantics the theoretical arguments that he later turned against them. Bornstein contended that Eliot had projected his own uncertainties onto the romantic poets to exorcise the weaknesses he feared were constitutive of his own poetry. All these critics acknowledged that the notion of being unambiguously antiRomantic was a methodologically questionable hypothesis, grounded as it was on the idea that reaction can be detached from what it seeks to evacuate and displace. Their contributions are of particular interest here since what is of concern to me at this stage is Eliot's use of the term "negative" in relation to Romanticism and its connection to nostalgia.

Eliot's choice of the word seems to sanction the inefficacy of Romanticism as a reaction to one's incapacitating fixation on the past. Yet the poem's rampant distrust of nostalgia and of the resurfacing of buried emotional attachments points to a similar reactive endeavour. The lugubrious note sounded at the end of the evocation of the river Thames ("But at my back in a cold blast I hear/The rattle of the bones, and chuckle spread from ear to ear." [185-6]) disgracefully upends Spenser's "Prothalamion." The same formula is repeated a few lines below ("But at my back from time to time I hear" [196]) to insinuate a suspicion of universal vanity (194-202). Every hint of a return is dysphorically connoted as ghostly, on the model of Dante's descent into the inferno, most prominently through the figure of Tiresias and that of the London crowd (61-64). The same obsessive and deflatory motif mars the mythological tale of the return of the conscripted soldier in the episode at the pub $(138,142)$. It also surfaces in lines 175-179, where the persona's sense of loss at the departure of the nymphs is immediately trivialized by the mention of the "loitering heirs of city directors." The visions of homecoming in lines 220-221, paradoxically used to introduce a new scene, similarly undercut any high expectations set by a possible return:

At the violet hour, when the eyes and back

Turn upward from the desk, when the human engine waits

Like a taxi throbbing waiting,

I Tiresias, though blind, throbbing between two lives,

old man with wrinkled female breasts, can see

At the violet hour, the evening hour that strives

Homeward, and brings the sailor home from sea,

The typist home at teatime, clears her breakfast, lights

Her stove, and lays out food in tins (Eliot, 2006 , 63-4, 1. 215-23)

If reminiscence is construed by the poet as an attribute of Romanticism, hence antinomic with Modernism, its disavowal is evidently a plain case of throwing out the baby with the bathwater. Measured against this rejection, Eliot comes off as a very moderate reactionary who after all is not so keen on the preservation of the past.

More importantly, as regards the conduct of my inquiry, if we adopt the poet's ambivalent construction of Romanticism as a misguided act of will, one which presumptuously pretends to effect the liberation from the old yet perversely remains in the thralls of nostalgic broodings, it is likely to come up again and again at every turn of our argumentation and obstruct our path, as it presumably stood in the way of the modernists when they attempted to put together a coherent authoritative declaration of intent. revolutionary and too sentimentally attached to the past? Obviously, it is the adverb 
"sentimentally" that confuses the issue. The more psychologically oriented commentators of Eliot, who detected in him a distrust of uncontrolled reminiscences, an insecurity towards feelings that endangered his masculine ideal of mastery (a disposition which would hardly predispose one to embrace poetry-writing as a career), frequently associated these qualms with the overpowering legacy of the Romantics. McIntire quotes a review penned by Yeats which reads: "T.S. Eliot published his first book-no Romantic word or sound, nothing reminiscent would be permitted henceforth" (my emphasis). ${ }^{9}$

If Romanticism is characterized by the predominance of affects or, as Baudelaire described it, "a way of feeling," one is led to wonder if it is also against it that the poetic persona reacts in The Waste Land, when affirming the comfort brought about by forgetfulness. In this scheme, turning against Romanticism would strangely come off as a cure to the artists' neurosis, a purge allowing them to divest themselves of their fixation on the old, a way of overcoming the paralyzing consciousness of their supposedly visceral attachments. I am tempted to think that it is the modernists' insuppressible embroilment with the past, and their compulsion (or determination) to act from contradictory principles that motivated their plans and set them into motion. The paradoxes of reaction could then be described as the dynamics that propelled their movement, like Deleuze's proverbial "desiring machines" that only work when they are out of order.

Lawrence Rainey perceives the combination of the two incompatible attitudes mentioned above as the very structure of modernism, and in his view, as far as Eliotian studies are concerned, there is no sense in opposing the closet Romantic to the classicist (Rainey 308-9). The author pragmatically concludes that the doctrinaire Eliot offers scant ground for criticism, and must be left alone simply because he is not conducive to research (except, perhaps, in the field of genetic criticism). As for the "histrionic" Eliot, who capitalizes upon effects of surprise and striking juxtapositions, he still demands the scholar's attention.

Eliot's own positions on the matter are unsystematic and not amenable to clear-cut dogmatic formulations. Many commentators have tried to disentangle this knot of contradictions, pitting the reactionary against the revolutionary and impersonality against the pure and unhampered expression of self, without suppressing altogether the critical ambivalence of Eliot's pronouncements. Sauerberg (29) argued that Eliot was far less vocal than other modernists on the issue of modernism versus Romanticism while other commentators noted that The Use of Poetry remained very circumspect on the notion that Classicism was the antidote to Romanticism, as developed by Charles Maurras and T. E. Hulme. The Waste Land implicitly seems to disclaim any totalizing ambition of the visionary poetic utterance, such as is commonly ascribed to Romanticism. Its personae do not demonstrate any particular disposition to deal with the overwhelming, and the obscure and cryptic remain prosaically so-mere mystifications with no hint of a metaphysical significance ("I could not / Speak, and my eyes failed").

Up to a certain point, our common understanding of the turnabouts and deviations of reaction-what is generally dubbed its dialectics-may account for these uncertainties. Every artist who seeks to overcome the conventions of his time has to prop his creative activity against a precedent that he construes as antithetical to his pursuits. But when that precedent itself exhibits a strong oppositional tendency as well as an ambition to 
correct the flaws of modernity, it may leave one with the bitter impression that it has preempted every term by which one's claim to a modern literature might be established. Such was the case with Romanticism, as it seemed to hold prior rights to the project of rejuvenation or re-founding of the literary activity, including its insistence on localism, its dynamics of reaction against the ideology of progress manifested in industrialism and whatever else was conducive to modernity. In short, it seemed that nothing was left to modernism that belonged to it in its own right. Such are the paradoxes of modernity that Scholes (2006), among others, have explored. Jeffrey Perl (1984) has also suggested that the paleo-modernists (Yeats, Pound, Eliot, Joyce) shared a strange historical construction that made it imperative for them, in order to move forward, to reach back to some foundational project located in a more ancient past. Now, if the new cannot be envisaged without the benefits of a tradition, that leaves one with two concurring traditions, and one incurs the moral responsibility of disowning a past to recuperate another.

\section{The Reaction to Reaction}

Nietzsche's understanding of reaction also has a particular contextual significance in the case that interests us and it is bound to figure in any historically grounded assessment of the poet, since a certain vulgarization of the philosopher's work operated as a zeitgeist dominating the intellectual climate in the first quarter of the twentieth century, although this position was certainly challenged by different varieties of Hegelian thought. Yet it was also much more influential in the literary field than in philosophy-especially in England. ${ }^{10}$ This preeminence might have been due to the fact that the pseudo-Nietzschean discourse was helpful to confront such literary questions as those of the legitimacy of criticism, of artistic elitism and the distinction between high and low literature. On these subjects, one may think of the enterprise undertaken by the editors of the little magazines such as The Criterion, who intended not only to be arbiters of taste or trendsetters, but more importantly purveyors of superior collective values. If Eliot's observations on the role of memory in writing were definitely an answer to Coleridge's own discussion of memory and imagination, they were also made in reference to the vulgarized digest of Nietzsche's work. Roughly speaking, Nietzsche's reflections on memory revolve around the idea of action and reaction, as opposed to the endless rumination of grudges and discontents. Reactive forces are not per se dangerous for one's mental health, he argues, as long as the reaction is immediate and takes as its object the tangible cause of one's affection: whatever excites our consciousness must be acted out and/or promptly forgotten. Otherwise it feeds a spirit of resentment and one is bound to feel again and again an emotion that was once caused by an actual event but that has been separated from it in time. In the process, one turns against oneself with all the violence of that longcontained anger (Deleuze 118-119).

Nietzsche is against resentment because it is an ugly, bitter emotion which the strong and powerful do not and cannot feel. Strong personalities who are politically or economically oppressed may also experience the most powerful feelings of resentment, but in them that emotion may even be a virtue. The difference, Nietzsche says, is that they act on it. They do not let it simmer and stew and "poison" the personality (Solomon 210). 
41

Nietzsche compares consciousness to a soft yet resilient material which registers external stimuli but soon recovers its integrity so that even the most brutal events impacting it cannot durably dent its surface. As for the traces, they only remain inscribed in a deeper wax-like layer of our mental constitution that he explicitly describes as the unconscious: memory is unconscious and being so, it does not torment or separate active forces from what they can do.

Ressentiment, therefore, is a malfunction, a displacement of the traces which contaminates the surface of consciousness. Conversely, forgetfulness is an active disposition which prevents such entrapment. As he puts it in The Genealogy of Morals, the good man does not hate or envy because he simply forgets.

On the face of it, it is difficult to imagine Eliot standing anywhere but at odds with Nietzsche's triumphalism, his perspectivism, and his promptitude to dismiss, on the basis of his general theory, any human trend that contradicts his scheme, while vindicating at the same time the right to contradict himself. Eliot's own compulsion to "tarry with the negative"11 (according to Žižek's phrase) does not allow him to ignore any "cultural" element belonging to a tradition just because it would thwart the unifying purpose of a poetic scheme. Thus, it has frequently been observed that there is in Eliot a form of negativity which enables the poetic subject or persona to encounter and recognize itself in lack and destitution, though not necessarily in guilt and abnegation (the moral values correlated to them), and it functions as a sort of poetic device or writing-script. In T.S. Eliot's Negative Way, Eloise K. Hay argues that Eliot starts from an attention to nothingness and refers this particular concern-as a method -to Pascal and Kierkegaard. Deleuze considers both authors as tragic philosophers, who may hold morality in suspense and invert reason, yet who remain caught in the net of resentment, and derive all their forces from an ascetic ideal: "in order to philosophize, they need all the resources of the guiding thread of interiority, anguish, wailing, guilt, all the forms of dissatisfaction," he writes (Deleuze 34, 36). ${ }^{12}$ Eliot himself expressed the opinion that The Waste Land was mostly a personal expression of dissatisfaction. From a Nietzschean point of view, we move here from a form of resentment which, though interiorized, is still directed at someone else to a Christian turn of mind, where the blame is turned inward against oneself.

have seen that the motif of the nostos was one of the two constitutive elements of the nostalgic affect (the one most evidently associated with reaction, when the conditions for creative action are not present or cannot be considered for moral reasons), together with the exploration of suffering, and possibly the perversity which consists in deriving satisfaction therefrom. Shall we then take the poem's "recoil from the chaos of life" (Davidson, 121) or "grouse against life" as a refutation of that Nietzschean heroic or tragic exultation that one finds in Yeats's poetry, as a negation of the affirmative life forces? It seems that the point is settled. From a Nietzschean point of view, positive assertion is not Eliot's forte. Dotted all over by repetitive expressions of a refusal to communicate or cooperate, by dodges and states of indecisive agitation, his project seems to unfold through no will of his own, indicating that Eliot works under the sway of resentment. But this is a construction of Nietzsche put together by his turn-of-the-century apologists.

In spite of the striking contrasts which apparently mark off the two authors, an unexpected resemblance may complicate our preconceptions about them. Just as Eliot's many recantations on the general principles that he had so staunchly affirmed in his 
early career have been used against him to belittle the breadth and scope of his declarations, Nietzsche has been derided because of the gap between his grandiose pronouncements and the evidence of his fragile constitution. In Ecce Homo, however, he provocatively acknowledges his own illness, weaving a metaphor that is strikingly similar to the situation exposed in the incipit of The Waste Land.

If anything at all needs to be counted against being ill, being weak, then it is the fact that in that state the true healing instinct, in other words the instinct for defence and weapons in man, is worn down. You cannot get rid of anything, you cannot cope with anything, you cannot fend anything off-everything hurts you. People and things get intrusively close, experiences affect you too deeply, memory is a festering wound. Being ill is a kind of resentment itself (Nietzsche, Ecce Homo 13) weakness, his confrontation to an abhorrent reality would have killed him, had he chosen to react to its offences. He admits that in such occasions, his salvation lied in enforced passivity.

The invalid has only one great remedy for it-I call it Russian fatalism, that fatalism without rebellion with which a Russian soldier who starts finding the campaign too hard finally lies down in the snow. Not taking, taking on, taking in anything at all any more-no longer reacting at all... The great good sense about this fatalism (which is not always just courage unto death), what makes it life-preserving amidst the most life-threatening of circumstances, is the reduction of the metabolism, the slowing of its rate, a kind of will to hibernation. Take this logic a few steps further and you have the fakir sleeping in a tomb for weeks on end... Since you would exhaust yourself too quickly if you reacted at all, you no longer react in any way: such is the logic. And nothing burns you up faster than the emotions of resentment. (Nietzsche, 2007 13, emphasis in the original)

This regressive image of "death in life," which had also persistently stirred Yeats's imagination, uncannily resembles the morbid stance of the (meta)poetic persona foregrounded in the incipit, its insistence on the preservation of a "neutral" ground to escape the trappings of personality which are illustrated by the subsequent series of incarnations or "slices of life" that constitute the substance of the first and second section of the poem. Thus understood, impersonality appears less as a doctrine than a vital necessity. The avoidance of any determination (of the sort that fleshes out the moments of affective intensity succeeding one another in The Waste Land, its nearrevelations and pseudo-epiphanies) realizes itself emotionally as a recoil in anticipation of the mood changes which subsequently affect it, as it goes through a whole range of emotional reactions denoting passive victimization: frustration, fear, guilt, helplessness, the sense of being overwhelmed and the pathetic realization of one's inadequacy. All in all, it amounts to a wholesale abstention from reactive affects, when "one does not know how to repulse anything." (Nietzsche 2007 18)

As the reader must have realized, the present article does not purport to cover the whole of Eliot's conception of time. Its focus has been narrowed down to the past conceived as a matter of resentment or grievous reminiscences. This explains why I have chosen to concentrate on Eliot's criticism of romanticism, for it evinces an inner turmoil conducive to that doubleness of purpose which I mostly wish to attend.

Undoubtedly, there are other ways of approach that would assign to the past a more constructive role in Eliot's poetry. Especially if, in Tung's terms, "the relation [between past and present] is constitutive and defining rather than purely different" (382), or if 
it is perceived as a yearning for a dismantled totality. The very word "fragment," as Longenbach observes, implies a whole that can potentially be reconstituted or at least intuited. To document that position, Longenbach considers the existentialist understanding of history of Dilthey, Croce, Bradley, Ortega y Gasset or Collingwood (13-14). It is certainly congruent with Bradley's notion of the absolute as transcendent experience (Brooker 153). It is also in keeping with the ideas of Bergson, although Eliot had begun to distance himself from the philosopher as early as 1911 (Lockerd 192). It promises an incorporation of the past into the present that substantiates the latter and reinforces one's embeddedness in time. In Dilthey, for instance, subjective perception is crucial to the historical construction. Yet this is precisely the subjectivity that Eliot finds embarrassing.

50 According to his conception, Longenbach argues, what permits an intimacy with the dead is a vision that collates the sundry fragments of the past. Yet these are only painfully brought together. Such is the disturbance that affects our dealing with the past. In this regard, it is not alien to the painful ordeal of nostalgic reminiscences. Yet that visionary gift is what Eliot descried in his essays on the Romantics. One cannot ignore that his rejection of Romanticism as a fraudulent claim to some supernatural afflatus was motivated by his precaution towards passionate creative impulses. To be sure, Eliot embraces ingenuity and percipience, but only within the framework of a theology which, since it allows of metaphysics and transcendence, tolerates visionary revelations.

\section{Conclusion}

51 A brief recapitulation shall serve as a conclusion to our study of reaction in The Waste Land. To begin, I have chosen to start from the affective dispositions and the orientation of desire because of their conspicuous thematic presence in the incipit. My presuppositions here were that: 1) the vital forces are at the core of the opening section of the poem, albeit in absentia, for the text is rid with persistent interrogations about what these forces could actually do. Yet even as such-metapoetically-they drive the poem, dynamizing it and providing continuity; 2) these yearnings and desires that propel the first section and push onward or fight back their way to some first object are integral to the workings of reaction; 3 ) the term Eros is more conducive to our reflexion than that of libido. The latter tends to fold back the study on a psychoanalytical hypothesis and an attendent psychologising which was precisely one of the two critical discourses whose explanatory power we doubted because of its universalizing and diffuse character. Moreover the Eros is more congruent with the Nietzschean understanding of desire briefly exposed above-indeed, Nietzsche's conceptions are those of a vitalist.

Now where do these admissions land us? The position of the reactionary subject has been systematically derided (often with good reasons) and consequently ruled out of the poetic equation as a sickly disposition which combines great will and great apprehension. It supposedly betrays a fear of any intrusion that would compromise the balance of the neurotic self: a cowardly determination to leave no chance to the new. But its presence as an operator and the ambivalence it elicits in the poet are far more subtle than this assessment can allow: eventually, the poem also partly-and contradictorily-espouses retentiveness as an active capacity. It is not a case of self- 
effacement of the author before the superior good of the poetic purpose. Rather, the process of holding back is "presented" as a strong-willed-if not powerfulaccomplishment: that of preserving something that does not properly belong to the individual subject. This is at least one way of accounting for the foundational paradoxes of the reactionary position: its insistence on discipline which calls for authority-an authority, however, that cannot be exercised in one's own name.

\section{BIBLIOGRAPHY}

\section{BIBLIOGRAPHY}

BERND, Magnus and Kathleen M. Higgins. The Cambridge Companion to Nietzsche. Cambridge University Press, 1996.

BORNSTEIN, George. Transformations of Romanticism in Yeats, Eliot, and Stevens. Chicago: University of Chicago Press, 1976.

BROOKER, Peter, and Andrew THACKER editors. Oxford Critical Cultural History of Modernist Magazines, vol. I, Britain and Ireland 1880-1955. Oxford: Oxford University Press, 2009.

BROOKER, Jewel S., and Joseph BENTLEY. Reading The Waste Land: Modernism and the Limits of Interpretation. Amherst: University of Massachusetts Press, 1990.

BROOKER, Jewel S. Mastery and Escape: T.S. Eliot and the Dialectic of Modernism. Amherst: University of Massachusetts Press, 1996.

BROOKER, Jewel S.“F. H. Bradley's Doctrine of Experience in T.S. Eliot's 'The Waste Land' and 'Four Quartets'." Modern Philology, vol. 77, no. 2, 1979, p. 146-157.

CASSEDY, Steven. Flight From Eden: The Origins of Modern Literary Criticism and Theory. Berkeley: University of California Press, 1990.

CHINITZ, David E., editor. A Companion to T. S. Eliot. Blackwell, 2009.

CRAWFORD, Fred. Mixing Memory and Desire: The Waste Land and British Novels. University Park: Pennsylvania State University Press, 1982.

DAVIDSON, Harriet. "Improper Desire: Reading The Waste Land." Cambridge Companion to T.S. Eliot. Ed. A. David Moody. Cambridge: Cambridge University Press, 1994, p. 121-131.

DELEUZE, Gilles. Nietzsche and Philosophy. Translated from the French by Hugh Tomlinson. New York: Continuum, 2006.

ELIOT, T.S., The Annotated Wasteland. Ed. Lawrence Rayney. New Haven: Yale University Press, 2006.

---. The Waste Land: A Facsimile and Transcript of the Original Drafts. Ed. Valerie Eliot. New York: Harcourt Brace Jovanovich, 1971.

---. The Use of Poetry and the Use of Criticism: Studies in the Relation of Criticism to Poetry in England. London: Faber, 1958. 
---. "A review of The Philosophy of Nietzsche, by A. Wolf." The Complete Prose of T.S. Eliot. The Critical Edition: Apprentice Years, 1905-1918. Ed. Spears Brooker, J. and R. Schuchard. Baltimore: Johns Hopkins University Press and Faber \& Faber, 2014. muse.jhu.edu/. Accessed 10 Jan. 2018. ELLMAN, Maud. The Poetics of Impersonality. Cambridge: Harvard University Press, 1988.

FAULKNER, Peter. A Modernist Reader: Modernism in England 1910-1930. London: Batsford,1986.

FERRALL, Charles. Modernist Writing and Reactionary Politics. Cambridge: Cambridge University Press, 2001.

FRAZER, Sir James. The Golden Bough. Vol. 1. London: MacMillan, 1894. www.gutenberg.org/. Accessed 13 Jan. 2018.

GRANT, Michael editor. The Critical Heritage. Vol. 1. London: Routledge, 1982.

KERMODE, Franck. Romantic Image. London: Routledge, 2002.

KNAPPS HAY, Eloise. T.S. Eliot's Negative Way. Cambridge: Harvard University Press, 1982.

LAMOS, Colleen. Deviant Modernism: Sexual and Textual Errancy in T.S Eliot, James Joyce, and Marcel Proust. Cambridge: Cambridge University Press, 2009.

LOBB, Edward. T.S. Eliot and the romantic critical tradition. London: Routledge \& Kegan Paul, 1981.

LOCKERD, Benjamin G. “'A People Without History.' A critique of Evolutionary History.” T.S. Eliot, France, and the Mind of Europe. Ed. Jayme Stayer. Newcastle upon Tyne: Cambridge Scholar Publishing, 2015, p. 188-203.

LONGENBACH, James. Modernist Poetics of History: Pound, Eliot, and the Sense of the Past. Princeton: Princeton University Press, 1988.

LUCKÁCS, Georg. “The Ideology of Modernism.” 1956. The Critical Tradition. Ed. David H. Richter. New York: St Martin Press, 1989.

NIETZSCHE, Friedrich. On the Genealogy of Morality. Translated from the German by Carol Diethe. Ed. Keith Ansell-Pearson. Cambridge: Cambridge University Press, 2002.

---. Ecce Homo, How One Becomes What One Is. Translated from the German by Duncan Large. Oxford: Oxford University Press, 2007.

MCINTIRE, Gabrielle. Modernism, Memory, and Desire: T.S. Eliot and Virginia Woolf. Cambridge: Cambridge University Press, 2008.

MOODY, David editor. The Cambridge Companion to T. S. Eliot. Cambridge: Cambridge University Press, 1989.

MORRISON, Paul. The Poetics of Fascism: Ezra Pound, T.S. Eliot, Paul de Man. Oxford: Oxford University Press, 1996.

PERL, Jeffrey M. The Tradition of Return: The Implicit History of Modern Literature. Princeton: Princeton University Press, 1984.

RAINEY, Lawrence. “Eliot's Poetics: Classicism and Histrionics." A Companion to T. S. Eliot. Ed. David E. Chinitz. Oxford: Oxford University Press, 2009, p. 308-309.

SAUERBERG, Lars O. Versions of the Past-Visions of the Future: The Canonical in the Criticism of T.S. Eliot, F.R. Leavis, Northrop Frye and Harold Bloom. London: Macmillan, 1997.

SCHOLES, Robert. Paradoxy of Modernism. New Haven: Yale University Press, 2006. 
SCHWARTZ, Delmore. “The Isolation of Modern Poetry.” The Kenyon Review, vol. 3, no. 2, 1941, p. 209-220.

SHUSTERMAN, Richard. T.S. Eliot and the Philosophy of Criticism. London: Duckworth, 1988.

SMITH, Grover. T.S. Eliot and the Use of Memory. Lewisburg: Bucknell University Press, 1996.

SOLOMON, Robert C. "Nietzsche Ad Hominem: Perspectivism, Personality and Ressentiment." The Cambridge Companion to Nietzsche. Eds. Bernd Magnus and Kathleen Higgins. Cambridge: Cambridge University Press, 1996, p. 180-222.

STEAD, C. K. The New Poetics: Yeats to Eliot. London: Hutchinson University Library, 1964.

TUNG, Charles M. "Modernist Contemporaneity: Rethinking Time in Eliot Studies and 'The Waste Land'." Soundings: An Interdisciplinary Journal, vol. 89, nos. 3-4, 2006, p. 379-403.

\section{NOTES}

1. The Oxford Cultural History of Little Magazines charts the continued influence of Nietzschean from The Savoy to New Age, New Coterie and Arts and Letters. Let it be clear that it is not our purpose to argue for a Nietzschean Eliot. Indeed the case would be very hard to make.

2. In The Use of Poetry and the Use of Criticism, Eliot repeatedly mentions the point on the subject of Blake (321), Wordsworth (74-5) and Shelley $(89,95-6)$, as well as Arnold $(113,115)$, but with a measure of ambivalence, since he simultaneously argues that, however different, morality and religion cannot be separated (97-99): it is just as tempting to read in such statements the suggestion that artists may have a philosophical turn of mind, but that they should not develop a philosophy of their own art.

3. According to Shusterman, "Eliot therefore insists that one's appreciation of poetry 'cannot be isolated from one's other interests and passions,' nor should it be. We must not ignore 'the doctrine, theory, belief, or 'view of life' presented in a poem' to concentrate exclusively on formal embellishments, for such an isolating focus deprives us of the enrichment poetry can give and leaves us not with pure poetry but only with 'the debris of poetry' [...] he openly asserts that literary criticism must not avoid ideology, that 'literary criticism should be completed by criticism from a definite ethical and theological standpoint.' Moreover, far from claiming that art and criticism are 'sealed from history' and social forces, Eliot in fact insists that they are largely constituted and changed through history, primarily 'due to elements which enter from the outside,' most especially 'social changes"' (6). Shusterman also cites the following passages in support of this view: "'the appreciation of art is an affair of limited and transient human beings existing in space and time' [...] For 'one's taste in poetry cannot be isolated from one's other interests and passions and must be limited as one's self is limited"' (6).

4. 'In America the tone was set very much by the 'Dial,' whose comments on the award were written presumably by Seldes, and by Edmund Wilson's review (no. 30), which Seldes commissioned [...] It has been suggested that Seldes himself understood very little of the poem, (8) and yet he saw a clear connection between the impersonality theory expressed in 'The Sacred Wood' and the poetry of 'The Waste Land,' a connection many later critics were to take up" (Grant 15).

5. Such an assessment dictated the plan of the 1994 Cambridge Companion, for instance.

6. In The Use of Poetry (145), Eliot refuses the notion of there being any common ground between poetic inspiration and mystical experience-that is he draws such lines. Yet, as it has already been pointed out, Shusterman goes a long way to demonstrate the contrary. 
7. In his account of Eliotian criticism, Michael Grant contends that by the fifties, Eliot had already become the target of increasingly judgmental opinions. (Leavis, his most faithful champion, had gradually changed his position and eventually defected to the side of D.H. Lawrence). See Grant 46.

8. As it produced culture, consequently modernism stood above it. Cassedy argues in Flight from Eden $(31,77)$ that New Criticism isolated the work of the author from the biography, thus concealing Eliot's intention. Here again, it must be observed that this does not reflect Eliot's position in The Use of Poetry.

9. Of course it might be argued that Yeats mostly projected on Eliot his misgivings about his own uneasy position as the "last of the Romantics."

10. The Cambridge Companion to Nietzsche $(282,292,307)$. Again, one may construe this form of Nietzscheanism as a reaction to German idealism, often conflated with Romanticism. Such idealism was equally rejected by the new practitioners of the philosophy of language whose influence, as Shusterman convincingly argues, was palpable in the literary circles of Bloomsbury and Garsington Manor, assiduously frequented by Eliot and Russell.

11. Some exemplary critical opinions have already been mentioned in the preceding pages. Even Wallace Stevens regards Eliot as "a negative rather than a positive force" (quoted by Leon Surette 15).

12. These are admittedly controversial and sweeping statements. The fulmination against resentment as a social passion is, naturally, the Nietzschean line or stroke, expeditious and irrevocable, that Deleuze prolongs in his own account of the philosopher. As his commentator, he adopts Nietzsche's deep scorn of negativity-which is born out of introspection.

\section{ABSTRACTS}

This paper explores the concept of reaction in relation to T.S. Eliot's poetry, unfolding its various implications as psychological motivation, temporal perception and political vision. It considers the possible relevance such factors might have had on the composition of The Waste Land. It first reviews the state of the art and recasts the different critical positions in a historical and cultural perspective, then reflects on what passes off as the fundamental rift between the commentators of Eliot, depending on whether they prescribe a close stylistic scrutiny of Eliot's poem or a general contextualisation as the premise of their literary assessment. On the face of it, the dispute revolves around the question of the author's responsibility and accountability for his work and the positions held by the contestants are liable to become entrenched, sometimes to the point of preventing the actual confrontation of critical insights.

Our contention will be that a simplification or standardization of the term "reaction" often obscures the fact that modernism is not simply contested or "in debate" but that modernism is the debate itself-in other words, that modernism is constitutively and structurally problematic. Modernism as manifested or endorsed by Eliot in the form of a writing programme consists precisely in that exposure to the conflict inherent in poetic practice, in the direct confrontation to insoluble dilemmas. These tensions, I argue, are located in the text itself and account for the strange thrust of its poetic move that withdraws instantly what it has just pushed forward.

Cet article s'attache au concept de réaction dans ses rapports avec la poésie d'Eliot. Il en déploie les diverses acceptions : motivation psychologique, perception temporelle et vision politique. 
Nous considérerons donc l'impact de ces différents facteurs sur la composition de The Waste Land. Nous commencerons par un état de l'art, en replaçant les multiples positions critiques dans une perspective historique et culturelle, et nous nous interrogerons sur le différend qui divise les commentateurs d'Eliot selon qu'ils prescrivent une étude stylistique rapprochée des poèmes ou choisissent au contraire d'aborder ceux-ci en référence à un contexte général qui inclut la biographie et les affirmations politiques d'Eliot. En apparence, cette discorde porte sur la question de la responsabilité de l'auteur vis-à-vis de sa poésie et de ses implications, compte tenu des affirmations d'Eliot à propos de la modernité démocratique. En conséquence, les acteurs de ce débat ont tendance à adopter des positions tranchées qui interdisent la confrontation des points de vue.

Notre hypothèse critique sera que la simplification et la standardisation du terme "réaction » obscurcit le fait que le modernisme n'est pas seulement au centre d'un débat polémique qui se formule en termes d'engagement du poète, mais que le modernisme est le débat même, qu'il est constitutivement et structurellement problématique. Pour cette raison, l'examen de la poésie d'Eliot requiert une présentation conjointe des pour et des contre. Le modernisme, tel qu'il s'affirme chez Eliot sous la forme d'un programme d'écriture, consiste précisément à s'exposer au conflit inhérent à la pratique poétique, à se confronter directement à son dilemme insoluble. Ces tensions critiques, ainsi que le propose cet essai, sont déjà inscrites dans The Waste Land, ce qui expliquerait son étrange progression par à-coups, où chaque avancée est immédiatement suivie d'un recul.

\section{INDEX}

Mots-clés: mémoire, modernisme, nostalgie, réaction, répétition, The Waste Land, T.S. Eliot

Subjects: Hors-thème

Keywords: memory, modernism, nostalgia, reaction, repetition, The Waste Land, T.S. Eliot

\section{AUTHOR}

\section{PHILIPPE BIRGY}

Université Toulouse- Jean Jaurès 